\title{
New record of Brachycephalus fuscolineatus Pie, Bornschein, Firkowski, Belmonte-Lopes \& Ribeiro, 2015 (Anura, Brachycephalidae) from Santa Catarina state, Brazil
}

\author{
Marcos Ricardo Bornschein ${ }^{1,2}$, Larissa Teixeira $^{1}$, Luiz Fernando Ribeiro ${ }^{2,3}$ \\ 1 Instituto de Biociências, Universidade Estadual Paulista (UNESP), Praça Infante Dom Henrique s/no, São Vicente, SP, CEP 11330-900, Brazil. \\ 2 Mater Natura, Instituto de Estudos Ambientais, Rua Lamenha Lins 1080, Curitiba, PR, CEP 80250-020, Brazil. 3 Escola de Ciências da Vida, \\ Pontifícia Universidade Católica do Paraná, Curitiba, Curitiba, PR, CEP 80215-901, Brazil. \\ Corresponding author: Marcos Ricardo Bornschein, bornschein.marcao@gmail.com
}

\begin{abstract}
Brachycephalus fuscolineatus Pie, Bornschein, Firkowski, Belmonte-Lopes \& Ribeiro, 2015 was described from Morro do Baú, Santa Catarina, Brazil. This species occurs at elevations of 640-790 m, and it is known to have an extent of occurrence of 23.63 ha. Here, we report a new record of B. fuscolineatus from Morro Braço da Onça, Luiz Alves, Santa Catarina. We recorded it on 21-22 December 2018 at elevations between 525 and 530 m; the new record occupied an area of 0.19 ha. We estimate 9 calling males in $36.35 \mathrm{~m}^{2}$.
\end{abstract}

\section{Key words}

Altitudinal distribution, Brachycephalus pernix group, conservation, montane forest, population density.

Academic editor: Raúl Maneyro | received 12 February 2019 | accepted 3 April 2019 | published 17 May 2019

Citation: Bornschein MR, Teixeira L, Ribeiro LF (2019) New record of Brachycephalus fuscolineatus Pie, Bornschein, Firkowski, Belmonte-Lopes \& Ribeiro, 2015 (Anura: Brachycephalidae) from Santa Catarina state, Brazil. Check List 15 (3): 379-385. http://doi.org/10.15560/15.3.379

\section{Introduction}

Brachycephalus Fitzinger, 1826 includes small diurnal anurans that inhabit the forest floor of Brazilian Atlantic Forest. Species from this genus have body lengths less than $2.5 \mathrm{~cm}$ and a reduced number and size of digits (e.g. Yeh 2007). Some species are brightly colored with neurotoxins in their skin (e.g. Schwartz et al. 2007). Several species are microendemic to one or a few mountain tops (Bornschein et al. 2016a), which highlights the need for conservation, especially because the number of species of the genus is underestimated. Brachycephalus currently includes 36 species, 22 of which have described in the last 10 years. Among these recently described species, 15 were described from southern Brazil, which reinforces the importance of additional studies for better estimating species richness of the genus and its conservation needs in southern mountains of Brazil.

During the last decades, our efforts were focused on the study and conservation of mountain fauna, with the description of new species (e.g. Langone et al. 2008, Maurício et al. 2014, Ribeiro et al. 2015, 2017, Bornschein et al. 2016b, Pie et al. 2018a), proposition of phylogenetic arrangements and biogeographic processes (e.g. Firkowski et al. 2016, Pulido-Santacruz et al. 2016, Maurício and Bornschein 2017, Pie et al. 2018b), and novelties of species distribution (e.g. Bornschein et al. 2012, 2016a, Teixeira et al. 2018). In this study, we present a new record for Brachycephalus fuscolineatus Pie, Bornschein, Firkowski, Belmonte-Lopes \& Ribeiro, 2015, a 
recently described species that until now was only known in its type locality (Ribeiro et al. 2015). In addition, to aid in the identification of new specimens, we reassess the color variation of the type series of B. fusculineatus.

\section{Methods}

We participated in field trips in high altitudes in order to find populations of Brachycephalus. We worked during the day, walking as quietly as possible along the margins of roads and trails, as well as in the interior of the forest, for acoustic identification of Brachycephalus. Upon detection of its particular sound, we approached to make recordings. After that, we removed the leaf litter to try to find specimens. We searched for Brachycephalus fuscolineatus at Morro Braço da Onça (21-22 December 2018) at 370-540 m above sea level (a.s.1.) in primary and secondary forests, Eucalyptus plantations, and palm (Archontophoenix alexandrae $\mathrm{H}$. Wendl. \& Drude) plantations. We collected specimens for identification and photographic documentation. ICMBio/SISBIO provided a collection permit (\#55918-1). We anaesthetized and euthanized specimens using $2 \%$ chloridrate lidocaine, fixed them in $10 \%$ formalin, and stored them in $70 \%$ ethyl alcohol solution. We deposited the specimens in the Museu de História Natural Capão da Imbuia (MHNCI), Curitiba, state of Paraná.
We recorded the geographical coordinates from points where B. fuscolineatus was found using a Garmin etrex 10 GPS (datum WGS84). We retrived the altitude of these points from Google Earth Pro v. 7.1.4.1529 when plotting the points, as in Bornschein et al. (2016a). We made a polygon connecting points of records of the species by the minimum convex polygon method using Google Earth, as recomended by IUCN (2012). We then estimated the area of the polygon using GEPath v. 1.4.5. We classified the area of the polygon as "extent of occurrence" or "area of occupancy" (IUCN 2012) in accordance with the distribution pattern of calling males (Bornschein et al 2016b), as homogenously distributed through the area (= area of occupancy) or patchily distributed (= extent of occurrence). We treated as patchily distributed locations in which we found patches with at least $2,500 \mathrm{~m}^{2}$ without records of calling males between patches with records of calling males that were just as large as or even larger.

We estimated calling males density of $B$. fuscolineatus as Bornschein et al. (2016b), Ribeiro et al. (2017), and Pie et al. (2018a). We walked slowly in the forest for about $0.5 \mathrm{~h}$, listening for individuals. In one place where we heard several males close to each other, we delimited the outer perimeter of a polygon by fixing a white line

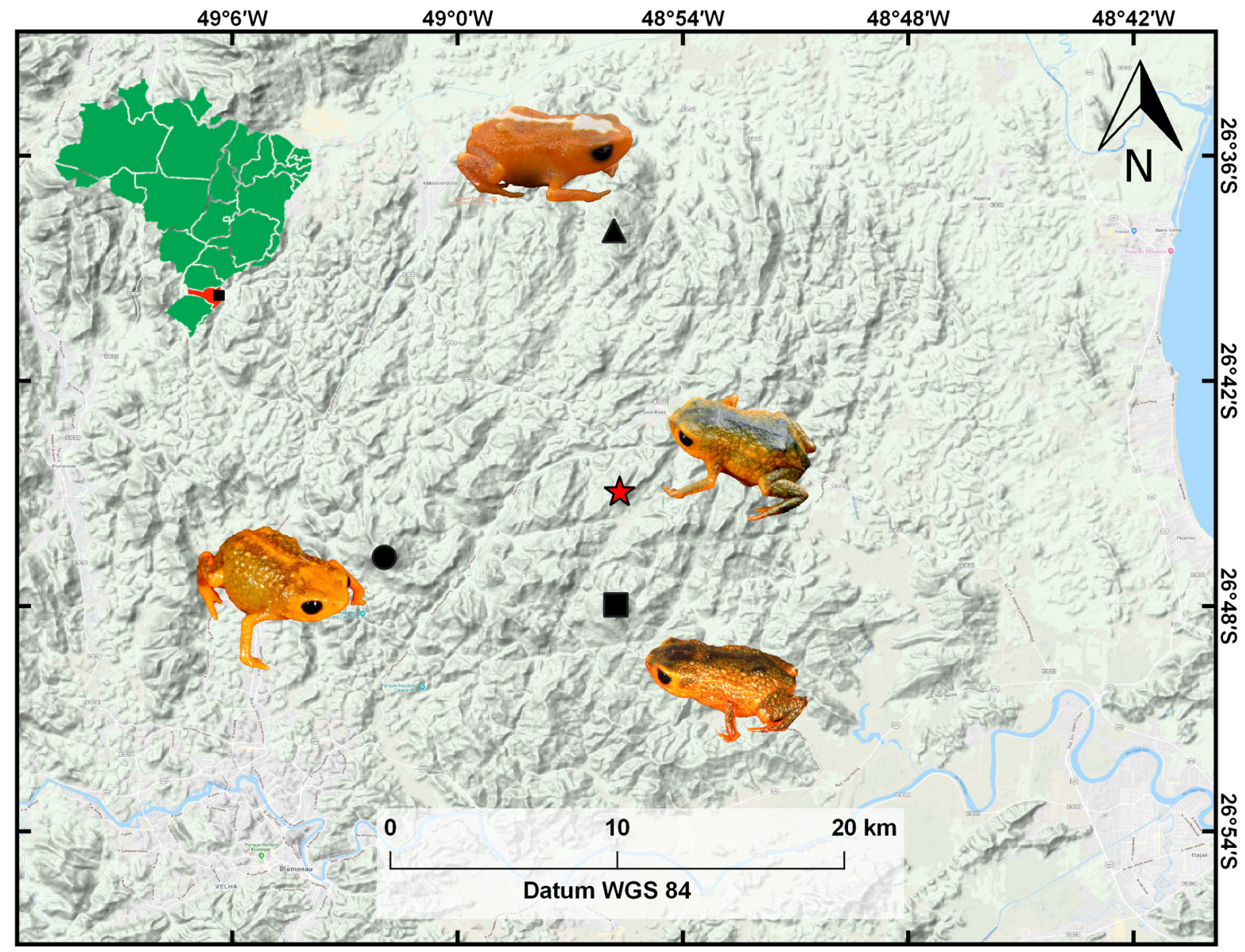

Figure 1. Geographic distribution of Brachycephalus fuscolineatus, showing the new record (red star) and previous records (black square) from the literature (Ribeiro et al. 2015), in Santa Catarina, southern Brazil. Type localities of B. boticario (black dot; Ribeiro et al. 2015) and B. mirissimus (black triangle; Pie et al. 2018a) are also indicated. 
Table 1. Estimated density of Brachycephalus spp.

\begin{tabular}{|c|c|c|c|c|c|c|}
\hline \multirow[b]{2}{*}{ Species } & \multirow[b]{2}{*}{ Locality, state } & \multirow[b]{2}{*}{$\begin{array}{l}\text { Altitude } \\
\text { (m a.s.l.) }\end{array}$} & \multirow[b]{2}{*}{$\begin{array}{l}\text { Sampled } \\
\text { area } \\
\left(\mathrm{m}^{2}\right)\end{array}$} & \multicolumn{2}{|c|}{ Density } & \multirow[b]{2}{*}{ Source } \\
\hline & & & & $\begin{array}{l}\text { One individual (in- } \\
\text { dependent of sex) } \\
\text { per area }\left(\mathrm{m}^{2}\right)\end{array}$ & $\begin{array}{c}\text { One male } \\
\text { per area }\left(m^{2}\right)\end{array}$ & \\
\hline \multicolumn{7}{|c|}{ B. didactylus group } \\
\hline \multirow[t]{13}{*}{$\begin{array}{l}\text { B. didactylus } \\
\text { (Izecksohn, } \\
\text { 1971) }\end{array}$} & $\begin{array}{l}\text { Fazenda Santa Bárbara, Parque Estadual } \\
\text { dos Três Picos, municipaliy Cachoeiras de } \\
\text { Macacu, Rio de Janeiro }\end{array}$ & $500-850$ & 625 & 25.0 & - & $\begin{array}{l}\text { Almeida-Santos et } \\
\text { al. } 2011\end{array}$ \\
\hline & $\begin{array}{l}\text { Fazenda Santa Bárbara, Parque Estadual } \\
\text { dos Três Picos, municipaliy Cachoeiras de } \\
\text { Macacu, Rio de Janeiro }\end{array}$ & $500-800$ & 625 & 25.0 & - & $\begin{array}{l}\text { Siqueira et al. } \\
2009\end{array}$ \\
\hline & $\begin{array}{l}\text { Monumento Natural Serra das Torres, } \\
\text { municipality of Atílio Vivacqua, Espírito } \\
\text { Santo }\end{array}$ & $600-900$ & 5,280 & 52.9 & - & Oliveira et al. 2013 \\
\hline & $\begin{array}{l}\text { Reserva Ecológica de Guapiaçu, } \\
\text { municipality of Cachoeiras de Macacu, Rio } \\
\text { de Janeiro }\end{array}$ & $300-520$ & 1,250 & 83.3 & - & $\begin{array}{l}\text { Siqueira et al. } \\
2014\end{array}$ \\
\hline & $\begin{array}{l}\text { Reserva Ecológica Rio das Pedras, } \\
\text { municipality of Mangaratiba, Rio de } \\
\text { Janeiro }\end{array}$ & $60-750$ & 750 & 83.3 & - & $\begin{array}{l}\text { Almeida-Santos et } \\
\text { al. } 2011\end{array}$ \\
\hline & $\begin{array}{l}\text { Reserva Rio das Pedras, municipality of } \\
\text { Mangaratiba, Rio de Janeiro }\end{array}$ & $20-750$ & 750 & 83.3 & - & Rocha et al. 2013 \\
\hline & \multirow{4}{*}{$\begin{array}{l}\text { Vila Dois Rios, Parque Estadual da Ilha } \\
\text { Grande, Ilha Grande, municipality of Angra } \\
\text { dos Reis, Rio de Janeiro }\end{array}$} & $220-230$ & 640 & 320 & - & \multirow[t]{4}{*}{ Rocha et al. 2000} \\
\hline & & $220-230$ & 640 & 160 & - & \\
\hline & & $220-230$ & 640 & 91.4 & - & \\
\hline & & $200-300$ & 2,560 & 20 & - & \\
\hline & \multirow{2}{*}{$\begin{array}{l}\text { Vila Dois Rios, Parque Estadual da Ilha } \\
\text { Grande, Ilha Grande, municipality of Angra } \\
\text { dos Reis, Rio de Janeiro }\end{array}$} & $220-230$ & 1,536 & 192.3 & - & \multirow[t]{2}{*}{ Rocha et al. 2001} \\
\hline & & $220-230$ & 180 & 5.6 & - & \\
\hline & $\begin{array}{l}\text { Vila Dois Rios, Parque Estadual da Ilha } \\
\text { Grande, Ilha Grande, municipality of Angra } \\
\text { dos Reis, Rio de Janeiro }\end{array}$ & $220-240$ & 468 & 5.1 & - & $\begin{array}{l}\text { Van-Sluys et al. } \\
2007\end{array}$ \\
\hline $\begin{array}{l}\text { B. hermogenesi } \\
\text { (Giaretta \& } \\
\text { Sawaya, 1998) }\end{array}$ & $\begin{array}{l}\text { Reserva Particular do Patrimônio } \\
\text { Natural Salto Morato, municipality of } \\
\text { Guaraquecaba, Paraná }\end{array}$ & $200-300$ & 2,560 & 100 & - & $\begin{array}{l}\text { Santos-Pereira et } \\
\text { al. } 2011\end{array}$ \\
\hline \multicolumn{7}{|c|}{ B. ephippium group } \\
\hline B. ephippium & $\begin{array}{l}\text { Serra do Japi, municipality of Jundiaí, São } \\
\text { Paulo }\end{array}$ & 1,000 & 1,344 & 1,344 & - & $\begin{array}{l}\text { Giaretta et al. } \\
1997\end{array}$ \\
\hline \multirow[t]{3}{*}{ B. pitanga } & \multirow{3}{*}{$\begin{array}{l}\text { Núcleo Santa Virgínea, Parque Estadual da } \\
\text { Serra do Mar, municipality of São Luiz do } \\
\text { Paraitinga, São Paulo }\end{array}$} & $?$ & $?$ & 0.8 & - & \multirow[t]{3}{*}{ Oliveira 2013} \\
\hline & & $?$ & $?$ & 0.8 & - & \\
\hline & & $?$ & $?$ & 0.7 & - & \\
\hline \multicolumn{7}{|l|}{ B. pernix group } \\
\hline \multirow[t]{2}{*}{ B. albolineatus } & \multirow{2}{*}{$\begin{array}{l}\text { Morro Boa Vista, on the border between } \\
\text { the municipalities of Jaraguá do Sul and } \\
\text { Massaranduba, Santa Catarina }\end{array}$} & $815-835$ & $?$ & - & $3-4$ & \multirow{2}{*}{$\begin{array}{l}\text { Bornschein et al. } \\
2016 \mathrm{~b}\end{array}$} \\
\hline & & 790 & $?$ & - & 100 & \\
\hline \multirow[t]{2}{*}{ B. curupira } & \multirow{2}{*}{$\begin{array}{l}\text { Serra do Salto, Malhada District, } \\
\text { municipality of São José dos Pinhais, } \\
\text { Paraná }\end{array}$} & 1,160 & $?$ & - & $2-3$ & \multirow[t]{2}{*}{ Ribeiro et al. 2017} \\
\hline & & 1,130 & $?$ & - & $6-7$ & \\
\hline B. fuscolineatus & $\begin{array}{l}\text { Morro Braço da Onça, municipality of Luiz } \\
\text { Alves, Santa Catarina }\end{array}$ & 530 & 36.35 & - & 4.0 & This study \\
\hline B. mirissimus & $\begin{array}{l}\text { Morro Santo Anjo, municipality of } \\
\text { Massaranduba, Santa Catarina }\end{array}$ & 535 & 202 & - & 14.5 & Pie et al. 2018a \\
\hline
\end{tabular}

on the vegetation and listened to the individuals inside it for $3 \mathrm{~h}$, placing short pieces of white strands in vegetation over the litter were we heard males. The effort was made by 2 people, that moved inside the polygon very slowly to confirm the position of the singers and to place the strands. We classified the vegetation of the region according to the Brazilian Vegetation Classification System (Veloso et al. 1991).

\section{Results}

New records. Brazil: Santa Catarina, municipality of Luiz

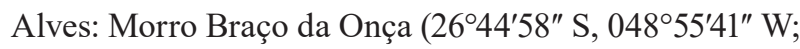

525-530 m a.s.1.) (Figs 1, 2), 22 December, 2018, coll. by Marcos R. Bornschein, Luiz F. Ribeiro, Larissa Teixeira, and Júlia Grigolato (MHNCI 10850-1; males; Fig. 3).

We found Brachycephalus fuscolineatus on 21-22 December 2018 in the leaf litter of primary forest (Floresta Ombrófila Densa Montana), about $15 \mathrm{~m}$ from the forest edge at 525-530 $\mathrm{m}$ a.s.l. Our estimation of the area of the polygon in which we heard males is only 0.19 ha of area of occupancy. We estimated 9 calling males within an area of $36.35 \mathrm{~m}^{2}$ (=1 male for every $4.0 \mathrm{~m}^{2}$; Table 1). The collected specimens were found inside curled leaves; one of specimens was on a large $(\mathrm{ca} 30 \mathrm{~cm})$ leaf of Bathysa australis (A.St.-Hil.) K.Schum. 


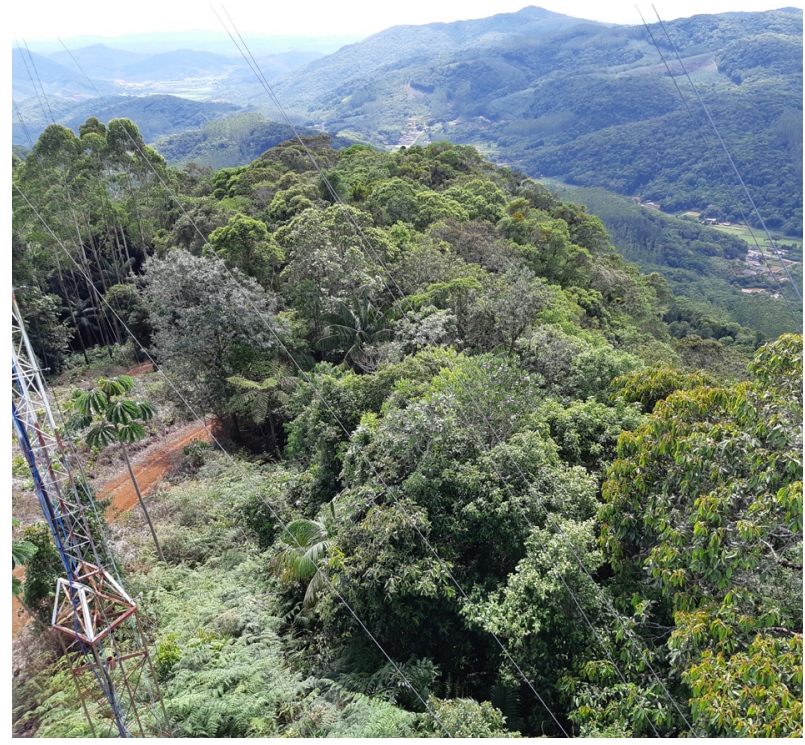

Figure 2. Top of the Morro Braço da Onça showing the slope in which we recorded Brachycephalus fuscolineatus, at least $15 \mathrm{~m}$ inland from the forest edge. In the left side, a part of the structures of a radio tower, opened areas, and Eucalyptus sp. can be observed. Urbanized areas can also be seen along a road, at lower altitudes. from the collected specimens. We compared these color characteristics among the collected specimens (see lists of these specimens in Ribeiro et al. 2015, 2017, Bornschein et al. 2016b, Pie et al. 2018a and Teixeira et al. 2018).

The original description of $B$. fuscolineatus (Ribeiro et al. 2015) does not report green in the dorsal stripe of this species, only brown. However, there was green coloration on the margin of the brown dorsal stripe of the holotype (Fig. 4) and paratypes (Fig. 5) of this species, similarly to the specimen of Morro Braço da Onça MHNCI 10850 (Fig. 3A). Actually, at least 2 paratypes (DZUP 160 and 404) show very little brown in a predominantly green dorsal stripe (Fig. 5C, D). On the contrary, the specimen collected in this study (MHNCI 10851; Fig. 3B) presents a dorsal stripe exclusively green, without traces of brown. The original description of B. fuscolineatus also does not report yellow coloration on the body, only orange. Nonetheless, some paratypes were indeed yellow color with a orange wash (Fig. 5), as was our specimens from Morro Braço da Onça.

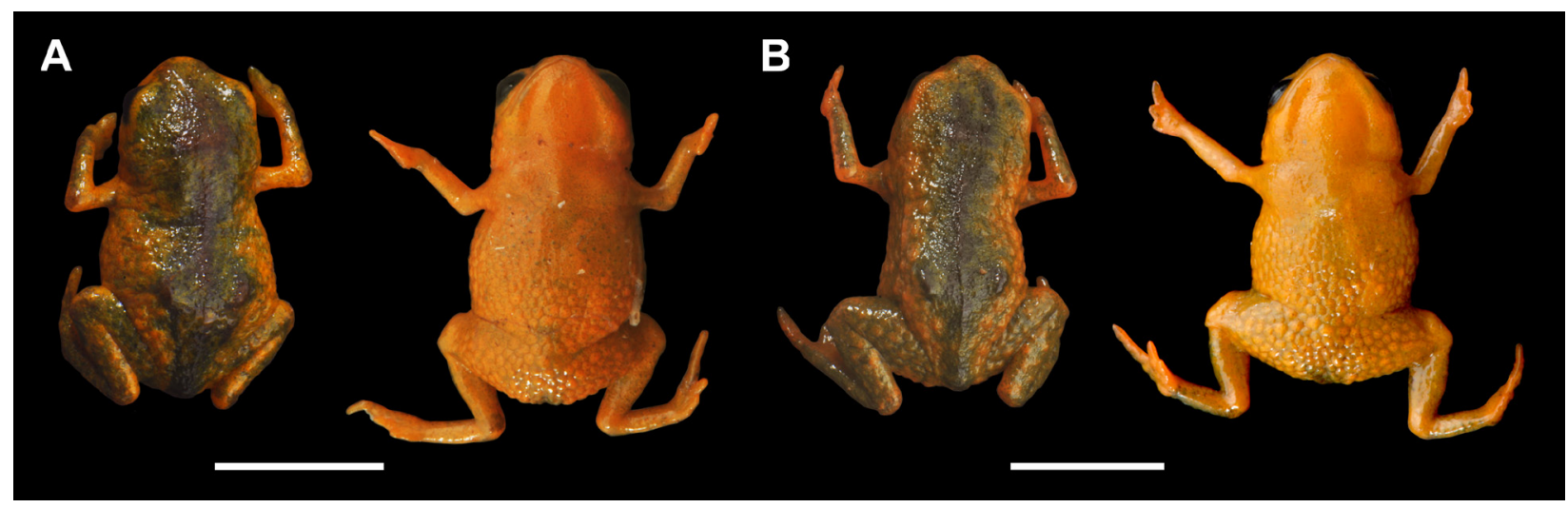

Figure 3. Males of Brachycephalus fuscolineatus collected at Morro Braço da Onça, municipality of Luiz Alves, Santa Catarina, southern Brazil. Live adults are shown in dorsal (left) and ventral (right) views. A. MHNCI 10850. B. MHNCI 10851. Abbreviation: $\mathrm{MHNCl}=\mathrm{Museu}$ de História Natural Capão da Imbuia, Curitiba, Paraná. Scale bar $=5 \mathrm{~mm}$.

Identification. The specimens collected are members of Brachycephalus pernix group by presenting a bufoniform body shape and linea masculinea (Pie et al. 2018a). Within this group, B. fuscolineatus can be distinguished from B. ferruginus Alves, Ribeiro, Haddad \& Reis, 2006, B. izecksohni Ribeiro, Alves, Haddad \& Reis, 2005, B. leopardus Ribeiro, Firkowski \& Pie, 2015, B. mariaeterezae Bornschein, Morato, Firkowski, Ribeiro and Pie, 2015, B. mirissimus Pie, Ribeiro, Confetti, Nadaline \& Bornschein, 2018, B. pombali Alves, Ribeiro, Haddad \& Reis, 2006, and B. tridactylus Garey, Lima, Hartmann \& Haddad, 2012 by having a broad greenish dorsal stripe, instead of entirely yellow or orange dorsal parts, or at least with a narrow blue stripe (B. mariaeterezae), white stripe (B. mirissimus), or orange dots (B. ferruginus) on dorsal parts. The remaining species of the $B$. pernix group have different pattern of body coloration and are very distinctive

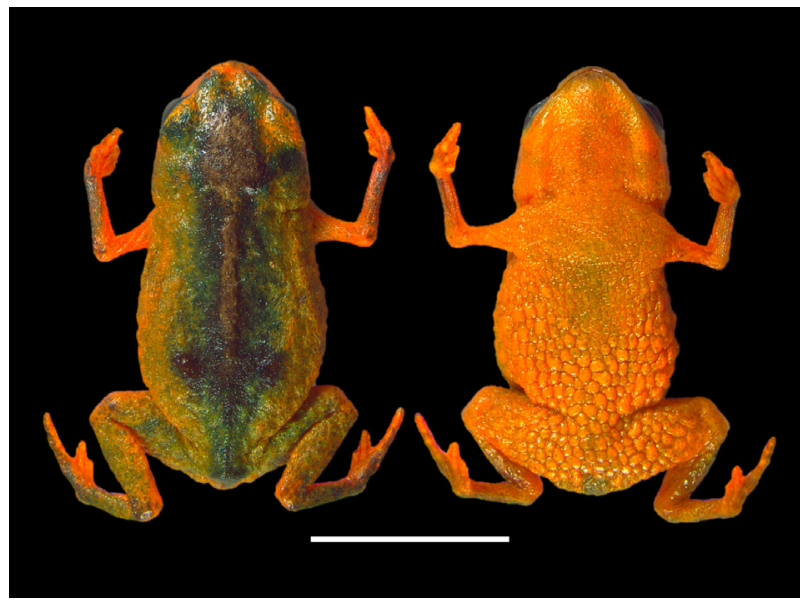

Figure 4. Holotype of Brachycephalus fuscolineatus DZUP 159 a few minutes after being killed and fixed in formalin, in dorsal (left) and ventral (right) view. Abbreviation: DZUP = Coleção Herpetológica do Departamento de Zoologia, Universidade Federal do Paraná, Curitiba, Paraná. Scale bar $=5 \mathrm{~mm}$. 


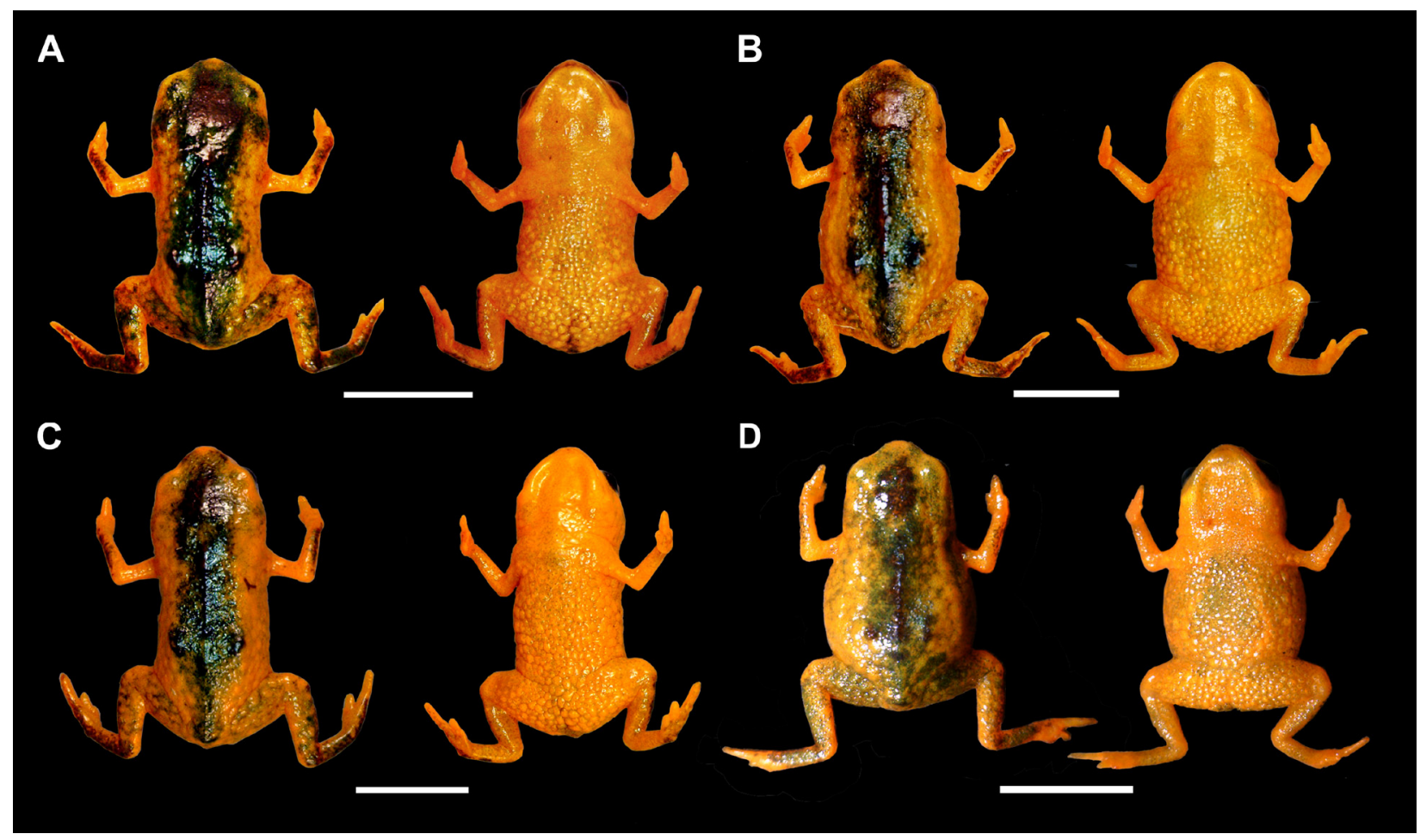

Figure 5. Paratypes of Brachycephalus fuscolineatus, all alive adults, in dorsal (left) and ventral (right) views. $A=D Z U P 402 ; B=D Z U P 401 ; C$ = DZUP 404; D = DZUP 160. Abbreviation: DZUP = Coleção Herpetológica do Departamento de Zoologia, Universidade Federal do Paraná, Curitiba, Paraná. Scale bar $=5 \mathrm{~mm}$.

\section{Discussion}

The new locality is $5.4 \mathrm{~km}$ north of the type locality of Brachycephalus fuscolineatus (Fig. 1). It is also 10.8 $\mathrm{km}$ east/northeast from the type locality of $B$. boticario (Ribeiro et al. 2015) and $13.4 \mathrm{~km}$ south of the type locality of B. mirissimus (Pie et al. 2018a; Fig. 1). The altitudinal range of occurrence of $B$. fuscolineatus is also extended with this new record. At the type locality, $B$. fuscolineatus was recorded at 640-790 $\mathrm{m}$ a.s.l. (Ribeiro et al. 2015), but we found it at 525-530 m a.s.l. in Morro Braço da Onça. Bornschein et al. (2016a) estimated an extent of occurrence in $23.63 \mathrm{ha}$, that is now extended to 23.82 ha.

The estimated density of $B$. fuscolineatus of 1 male every $4.0 \mathrm{~m}^{2}$ is lower than that estimated for $B$. curupira Ribeiro, Blackburn, Stanley, Pie \& Bornschein, 2017 (1 male each 2-3 $\mathrm{m}^{2}$ ) and is similar to the estimate for $B$. albolineatus Bornschein, Ribeiro, Blackburn, Stanley \& Pie, 2016 (1 male each 3-4 $\left.\mathrm{m}^{2}\right)$ but greater than that obtained for B. mirissimus (1 male each $14.5 \mathrm{~m}^{2}$; Table 1). All these estimates counted calling males of species of the B. pernix group (Table 1). In Table 1, we compiled other estimates of densities for Brachycephalus (data for both males and females). There are estimates of densities as high as 1 individual per less that $1 \mathrm{~m}^{2}$ for $B$. pitanga Alves, Sawaya, Reis \& Haddad, 2009, as well as reduced densities such as 1 individual in $1,344 \mathrm{~m}^{2}$ for B. ephippium (Spix, 1824), both of the B. ephippium group (Table 1). Due to the differences in methods, we consider the proportion of 1 female for each male singer sampled, reducing by half the estimated area for individuals of $B$. albolineatus, B. curupira, B. fuscolineatus, and B. mirissimus, regardless of sex.

The fauna and flora from Morro Braço da Onça presents a mixture of montane and low-altitude elements. Other species recorded at the locality, apart from B. fuscolineatus, are typically montane birds (Attila phoenicurus Pelzeln, 1868, Carpornis cucullata (Swainson, 1821), and Scytalopus speluncae (Ménétriès, 1835); taxonomy according to Maurício et al. 2010). Species that are indicative of lowland or submontane forests include the plants Attalea dubia (Mart.) Burret, Bathysa australis, Cecropia glaziovii Snethl., Euterpe edulis Mart., Geonoma gamiova Barb.Rodr., and Guadua angustifolia Kunth and the bird Phylloscartes kronei Willis \& Oniki, 1992.

The restricted area of occurrence we estimated for B. fuscolineatus at Morro Braço da Onça was surprising. This locality is highly degraded by the presence of roads, the edge effects of openings in the forest along the edges of roads (which let in sunlight and lower the humidity), palm and Eucalyptus plantations, and the use of herbicides. We do not know if deforestation has reduced the area of occurrence of the species at this locality, although deforestation reduces moisture at the edge of forest (Laurance et al. 2002) and affects the distribution of species. In Morro Braço da Onça, we only recorded B. fuscolineatus $15 \mathrm{~m}$ away from the forest edges. We also recorded this species only at $525-530 \mathrm{~m}$ a.s.l., despite also searching at $350 \mathrm{~m}$ a.s.l. and above. Brachycephalus fuscolineatus is a member of the B. pernix group (Ribeiro et al. 2015), a montane group with 
few records at lower altitudes (Bornschein et al. 2016a). Additionally, the Morro Braço da Onça is in a region that was predicted as having low climatic suitability for the occurrence of Brachycephalus (Pie et al. 2013). We do not rule out the possibility that Morro Braço da Onça represents a relict distribution, probably highly reduced by climate change and deforestation.

Although the forests at the type locality of B. fuscolineatus are more intact and the species there has a greater extent of occurrence (Bornschein et al. 2016a), its presence in fragments such as those reported here may be important for monitoring population trends. In the long term, population decline and changes in vegetation, might be first noticed in smaller fragments than in larger ones.

The precarious state of conservation of eastern mountains of Santa Catarina, including Morro Braço da Onça is worrisome. The mountains of this region are strategic places for the installation of cellphone towers, which can result in the suppression of vegetation along roads, construction of power plants and common housing, accumulation of construction and tourist waste on mountain slopes, introduction of invasive alien plants, and selective cutting of trees, among other impacts. The mountains are also excellent areas for the expansion of Eucalyptus and Pinus plantations and for the cultivation of the palm Archontophoenix alexandrae. There are 4 species of Brachycephalus endemic of only 1 or 2 mountains in eastern Santa Catarina state (B. albolineatus, B. boticario, B. fuscolineatus, and B. mirissimus), and many threats occur in this area. It is therefore important to search the region for new occurrences of these species and to find areas of priority for conservation and species management.

\section{Acknowledgements}

We are thankful to the National Geographic Society for covering the costs of the expedition (grant EC-50722R-18). LT is a FAPESP fellow (process 17/21611-9). We also thank Júlia Grigolato for help in the field and Carina Rauen Firkowski for help with some photographs of specimens. Elaine Lucas provided valuable comments that improved the quality of the manuscript.

\section{Authors' Contributions}

MRB, LFR, and LT participated on field work and data collection; MRB and LFR conducted the analysis; MRB wrote the text; LFR and MRB took photographs.

\section{References}

Almeida-Santos M, Siqueira CC, Van Sluys M, Rocha CFD (2011) Ecology of the Brazilian flea frog Brachycephalus didactylus (Terrarana: Brachycephalidae). Journal of Herpetology 45: 251255. https://doi.org/10.1670/10-015.1

Bornschein MR, Corrêa L, Belmonte-Lopes R, Klemann Júnior L, Cáceres NC, Pie MR (2012) The use of highlands by the Lowland
Tapir (Tapirus terrestris) in the southern Brazilian Atlantic Forest. Neotropical Biology and Conservation 7: 210-213. https://doi. org $/ 10.4013 /$ nbc.2012.73.07

Bornschein MR, Firkowski CR, Belmonte-Lopes R, Corrêa L, Ribeiro LF, Morato SAA, Antoniazzi-Jr. RL, Reinert BL, Meyer ALS, Cini FA, Pie MR (2016a) Geographic and altitudinal distribution of Brachycephalus Fitzinger (Anura: Brachycephalidae) endemic to the Brazilian Atlantic Rainforest. PeerJ 4: e2490. https://doi. org $/ 10.7717 /$ peerj. 2490

Bornschein MR, Ribeiro LF, Blackburn DC, Stanley EL, Pie MR (2016b) A new species of Brachycephalus (Anura: Brachycephalidae) from Santa Catarina, southern Brazil. PeerJ 4: e2629. https://doi.org/10.7717/peerj.2629

Firkowski CR, Bornschein MR, Ribeiro LF, Pie MR (2016) Species delimitation, phylogeny and evolutionary demography of co-distributed, montane frogs in the southern Brazilian Atlantic Forest. Molecular Phylogenetics and Evolution 100: 345-360. https://doi. org/10.1016/j.ympev.2016.04.023

Giaretta AA, Sawaya RJ, Machado G, Araújo MS, Facure KG, Medeiros HF, Nunes R (1997) Diversity and abundance of litter frogs at altitudinal sites of Serra do Japi, southeastern Brazil. Revista Brasileira de Zoologia 14: 341-346. https://doi. org/10.1590/S0101-81751997000200008

Langone JA, Segalla MV, Bornschein M, Sá RO de (2008) A new reproductive mode in the genus Melanophryniscus Gallardo, 1961 (Anura: Bufonidae) with description of a new species from the state of Paraná, Brazil. South American Journal of Herpetology 3: 1-9. https://doi.org/10.2994/1808-9798(2008)3[1:ANRMIT]2.0.CO;2

Laurance WF, Lovejoy TE, Vasconcelos HL, Bruna EM, Didham RK, Stouffer PC, Gascon C, Bierregaard RO, Laurance SG, Sampaio E (2002) Ecosystem decay of Amazonian forest fragments: a 22-year investigation. Conservation Biology 16: 605-618. https:// doi.org/10.1046/j.1523-1739.2002.01025.x

Maurício GN, Belmonte-Lopes R, Pacheco, JF, Silveira LF, Whitney BM, Bornschein MR (2014) Taxonomy of "Mouse-colored Tapaculos" (II): an endangered new species from the montane Atlantic Forest of southern Bahia, Brazil (Passeriformes: Rhinocryptidae: Scytalopus). The Auk 131: 643-659. https://doi.org/10.1642/auk$14-16.1$

Maurício GN, Bornschein MR, Vasconcelos MF de, Whitney BM, Pacheco JF, Silveira LF (2010) Taxonomy of "Mousecolored Tapaculos". I. On the application of the name Malacorhynchus speluncae Ménétriés, 1835 (Aves: Passeriformes: Rhinocryptidae). Zootaxa 2518: 32-48. https://doi.org/10.11646/ zootaxa.2518.1.2

Maurício GN, Bornschein MR (2017) On identification errors in Scytalopus speluncae (Ménétriés) and S. pachecoi Maurício from southern Brazil with new data on distribution and biogeography of these taxa (Aves: Rhinocryptidae). Zootaxa 4350: 595-599. https://doi.org/10.11646/zootaxa.4350.3.13

Oliveira EG (2013) História natural de Brachycephalus pitanga no núcleo Santa Virgínia, Parque Estadual da Serra do Mar, estado de São Paulo. MSc dissertation, Universidade Estadual Paulista "Júlio de Mesquita Filho", Rio Claro, 78 pp.

Oliveira JCF, Pralon E, Coco L, Pagotto RV, Rocha CFD (2013) Environmental humidity and leaf-litter depth affecting ecological parameters of a leaf-litter frog community in an Atlantic Rainforest area. Journal of Natural History 47: 1-10. https://doi.org/10.10 80/00222933.2013.769641

Pie MR, Meyer ALS, Firkowski CR, Ribeiro LF, Bornschein MR (2013) Understanding the mechanisms underlying the distribution of microendemic montane frogs (Brachycephalus spp., Terrarana: Brachycephalidae) in the Brazilian Atlantic Rainforest. Ecological Modelling 250: 165-176. https://doi.org/10.1016/j. ecolmodel.2012.10.019

Pie MR, Ribeiro LF, Confetti AE, Nadaline MJ, Bornschein MR (2018a) A new species of Brachycephalus (Anura: Brachycephalidae) from southern Brazil. PeerJ 6: e5683. https://doi.org/10.7717/ 
peerj. 5683

Pie MR, Faircloth BC, Ribeiro LF, Bornschein MR, McCormack JE (2018b) Phylogenomics of montane frogs of the Brazilian Atlantic Forest is consistent with isolation in sky islands followed by climatic stability. Biological Journal of the Linnean Society 125 : 72-82. https://doi.org/10.1093/biolinnean/bly093

Pulido-Santacruz P, Bornschein MR, Belmonte-Lopes R, Bonatto SL (2016) Multiple evolutionary units and demographic stability during the last glacial maximum in the Scytalopus speluncae complex (Aves: Rhinocryptidae). Molecular Phylogenetics and Evolution 102: 86-96. https://doi.org/10.1016/j.ympev.2016.05.027

Ribeiro LF, Bornschein MR, Belmonte-Lopes R, Firkowski CR, Morato SAA, Pie MR (2015) Seven new microendemic species of Brachycephalus (Anura: Brachycephalidae) from southern Brazil. PeerJ 3: e1011. https://doi.org/10.7717/peerj.1011

Ribeiro LF, Blackburn DC, Stanley EL, Pie MR, Bornschein MR (2017) Two new species of the Brachycephalus pernix group (Anura: Brachycephalidae) from the state of Paraná, southern Brazil. PeerJ 5: e3603. https://doi.org/10.7717/peerj.3603

Rocha CFD, Van Sluys M, Alves MAS, Bergallo, HG, Vrcibradic D (2000) Activity of leaf-litter frogs: when should frogs be sampled? Journal of Herpetology 34: 285-287.

Rocha CFD, Van Sluys M, Alves MAS, Bergallo HG, Vrcibradic D (2001) Estimates of forest floor litter frog communities: A comparison of two methods. Austral Ecology 26: 14-21. https://doi. org/10.1111/j.1442-9993.2001.01073.pp.x

Rocha CFD, Vrcibradic D, Kiefer MC, Almeida-Gomes M, BorgesJunior VNT, Menezes VA, Ariani CV, Pontes JAL, GoyannesAraújo P, Marra RV, Guedes DM, Siqueira C da C, Van Sluys M (2013) The leaf-litter frog community from Reserva Rio das Pedras, Mangaratiba, Rio de Janeiro State, Southeastern Brazil: species richness, composition and densities. North-Western Journal of Zoology 9: 151-156.

Santos-Pereira M, Candaten A, Milani D, Oliveira FB, Gardelin J, Rocha CFD (2011) Seasonal variation in the leaf-litter frog community (Amphibia: Anura) from an Atlantic Forest area in the
Salto Morato Natural Reserve, southern Brazil. Zoologia 28: 755-761. https://doi.org/10.1590/S1984-46702011000600008

Schwartz CA, Castro MS, Pires Jr. OR, Maciel NM, Schwartz ENF, Sebben A (2007) Princípios Bioativos da Pele de Anfíbios: Panorama Atual e Perspectivas. In: Nascimento LB, Oliveira ME (Eds) Herpetologia no Brasil II. Sociedade Brasileira de Herpetologia, Belo Horizonte, 146-168.

Siqueira CC, Vrcibradic D, Almeida-Gomes M, Borges-Junior VNT, Almeida-Santos P, Almeida-Santos M, Ariani CV, Guedes DM, Goyannes-Araújo P, Dorigo TA, Van Sluys M, Rocha CFD (2009) Density and richness of leaf litter frogs (Amphibia: Anura) of an Atlantic Rainforest area in the Serra dos Órgãos, Rio de Janeiro state, Brazil. Zoologia 26: 97-102. https://doi.org/10.1590/S198446702009000100015

Siqueira CC, Vrcibradic D, Nogueira-Costa P, Martins AR, Dantas L, Gomes VLR, Bergallo HG, Rocha CFD (2014) Environmental parameters affecting the structure of leaf-litter frog (Amphibia: Anura) communities in tropical forests: A case study from an Atlantic Rainforest area in southeastern Brazil. Zoologia 31: 147-152. https://doi.org/10.1590/S1984-46702014000200005

Teixeira L, Ribeiro LF, Corrêa L, Confetti AE, Pie MR, Bornschein MR (2018) A second record of the recently described Brachycephalus albolineatus Bornschein, Ribeiro, Blackburn, Stanley \& Pie, 2016 (Anura: Brachycephalidae). Check List 14: 1013-1016. https://doi.org/10.15560/14.6.1013

Van Sluys M, Vrcibradic D, Alves MAS, Bergallo HG, Rocha CFD (2007) Ecological parameters of the leaf-litter frog community of an Atlantic Rainforest area at Ilha Grande, Rio de Janeiro state, Brazil. Austral Ecology 32: 254-260. https://doi.org/10.1111/j.14 42-9993.2007.01682.x

Veloso HP, Rangel-Filho ALR, Lima JCA (1991) Classificação da Vegetação Brasileira, Adaptada a um Sistema Universal. Instituto Brasileiro de Geografia e Estatística, Rio de Janeiro, 123 pp.

Yeh J (2007) The effect of miniaturized body size on skeletal morphology in frogs. Evolution 56: 628-641. https://doi.org/10.1111/j. 0014-3820.2002.tb01372.x 